\begin{tabular}{|l|l|l||}
\hline \multicolumn{2}{|c|}{ PublisherInfo } \\
\hline \hline PublisherName & $:$ & BioMed Central \\
\hline \hline PublisherLocation & $:$ & London \\
\hline \hline PublisherImprintName & $:$ & BioMed Central \\
\hline \hline
\end{tabular}

\title{
Unraveling worm biology in the post-genomic era
}

\begin{tabular}{|l|l|l||}
\hline \multicolumn{2}{|c|}{ ArticleInfo } \\
\hline \hline ArticleID & $:$ & 4298 \\
\hline \hline ArticleDOI & $:$ & $10.1186 /$ gb-2001-3-1-reports2005 \\
\hline \hline ArticleCitationID & $:$ & reports2005 \\
\hline \hline ArticleSequenceNumber & $:$ & 30 \\
\hline \hline ArticleCategory & $:$ & Web report \\
\hline \hline ArticleFirstPage & $:$ & 1 \\
\hline \hline ArticleLastPage & $:$ & 3 \\
\hline \hline & & RegistrationDate : 2001-11-6 \\
ArticleHistory & $:$ & Received $\quad: 2001-11-6$ \\
& $:$ OnlineDate $\quad$ 2001-12-21 \\
\hline \hline ArticleCopyright & $:$ & BioMed Central Ltd2001 \\
\hline \hline ArticleGrants & $:$ & \\
\hline \hline
\end{tabular}




\begin{tabular}{|l|l|l|}
\hline ArticleContext & $:$ & 130593311 \\
\hline
\end{tabular}

\section{Chang-Su Lim}

\section{Abstract}

WormBase aims to provide scientists with easily accessible and timely information on the genetics and biology of the nematode Caenorhabditis elegans as well as on some closely related nematodes.

\section{Content}

WormBase aims to provide scientists with easily accessible and timely information on the genetics and biology of the nematode Caenorhabditis elegans as well as on some closely related nematodes. Many international biologists and bioinformaticians contribute to WormBase. It is the most comprehensive site for genomic information in C. elegans and contains a vast amount of information. Great effort has been put in to make this information both as current and as intuitively organized as possible. The site has several important features, including summary tables, DNA sequence, feature tables and genetic maps of the worm genome. The researcher can use a broad range of text-based and graphic search tools to search for genes and related information, especially now that the genome sequence of $C$. elegansis completed. The site incorporates a great deal of functional genomic information, including gene expression data and phenotypic analysis data from large-scale RNA inteference (RNAi) screens.

\section{Navigation}

WormBase is easily accessed with the usual web browsers. Versions of the database as well as the ACeDB software engine are downloadable, but this requires some computer literacy. Under the heading 'DNA Sequence', there are links to the complete chromosome sequences. If 'I' is clicked, for example, the browser shows the entire sequence of chromosome I. To obtain a graphic display of a region of the chromosome I genetic map, choose the chromosome I link in the 'Genetic Maps' section and type in the required area (in terms of genetic map distance). The site is fairly easy to navigate.

\section{Reporter's comments}




\section{Timeliness}

It is updated fortnightly.

\section{Best feature}

It is fantastic that one can simply navigate around a comprehensive resource of biological information on C. elegans, including genomics. This site can only get better as more data become available.

\section{Worst feature}

Advanced retrieval is not user-friendly. Advanced searching appears to be frequently bug-ridden or semi-functional. This may be because the site is constantly being updated or it is still under construction.

\section{Related websites}

The Caenorhabditis elegansWWW server is another useful site with links to information about the nematode.

\section{Table of links}

Wormbase

Caenorhabditis elegans WWW server

\section{References}

1. Wormbase. 